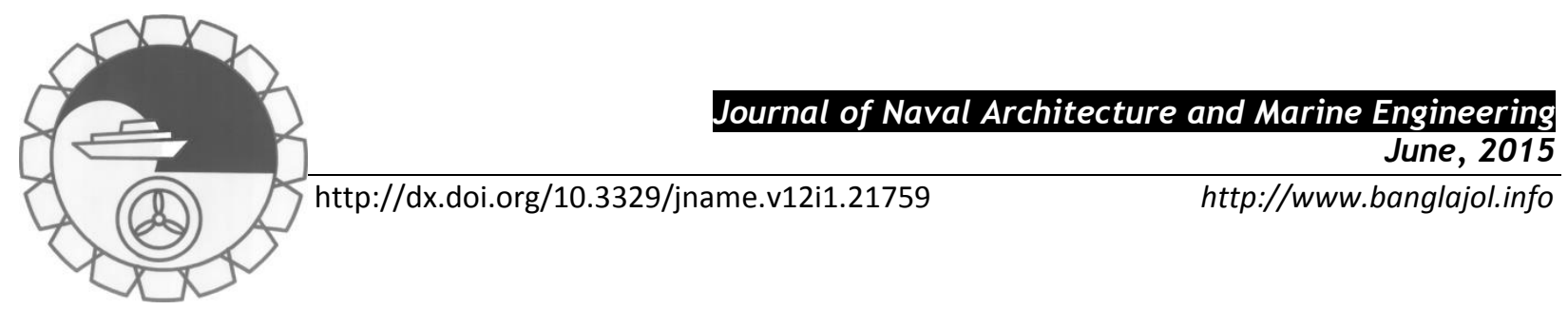

\title{
CURRENT STATE AND PERSPECTIVES OF THE CROATIAN SHIPBUILDING INDUSTRY
}

\author{
N. Hadžićc ${ }^{*}$, M. Tomić ${ }^{1}$, N. Vladimir ${ }^{1}$, S. Ostojić ${ }^{2}$, I. Senjanović ${ }^{1}$ \\ ${ }^{1}$ Faculty of Mechanical Engineering and Naval Architecture, University of Zagreb, Ivana Lučića 5, 10000 Zagreb, Croatia \\ "Email: neven.hadzic@fsb.hr \\ ${ }^{2}$ Croatian Shipbuilding Corporation, Avenija V. Holjevca 20, 10020 Zagreb, Croatia
}

\begin{abstract}
:
Shipbuilding is one of the most important manufacturing industries in Croatia involved in ships and offshore units' production, maintenance, repair and installation with a significant impact on Croatian economy and society. Current state of the Croatian shipbuilding industry is presented herein, based on the most recent available data on global and domestic shipbuilding activities and important conclusions and recommendations for its future development are drawn considering current state of the world shipping and shipbuilding databases. Future perspectives are addressed through analysis of current negotiation potential of suppliers and buyers as well as with respect to the rivalry among competitors. An importance of stable financial background and development of the domestic industrial surroundings is pointed out. Along with that, current Croatian industrial 2020 strategy is addressed in order to enhance its application within the existing shipbuilding infrastructure as well as within Croatian economy. Finally, energy, food and entertainment market sectors are pointed out as the most perspective sectors capable of influencing future Croatian society, economy, science and technology.
\end{abstract}

Keywords: Shipbuilding industry, Croatian economy, industrial strategy, Porter's model, merchant and special ship

\section{Introduction}

As one of the Croatian economy's key component, shipbuilding is an important industry branch that produces new and performs conversions and repairs of existing ships and offshore units. Except for long traditional values, it is represented by technologically demanding, recognizable, large scale, complex and usually small number of high capital value final products that make them Croatia's most valuable export commodities made for highly demanding and competitive global market. As it is strongly related to local industrial surroundings it is considered to be an industrial primemover that creates new jobs and enhances a local and regional community development. As estimated, one working place in Croatian shipbuilding has a potential to create additional $3-5$ jobs in its industrial surroundings, (Kersan-Škabić, 2009). Although it is often related to low profitability and harsh global competitiveness, shipbuilding industry has an important strategic role represented by the industrial surrounding multiplicative factor that in terms of current Croatian shipbuilding takes a value of about 2.8, (Perić Hadžić, 2013). In addition to that, shipbuilding industry depends on current state of the seaborne trade as the most important global commodities transport component, as well as on the world merchant fleet and world orderbook state, raw material prices, currency fluctuations, oil and gas market, geopolitical and geostrategic affairs, local economic policies, international trade associations, different legal aspects related to humans, environment and animals protection, availability of the bank loans, etc., which make it very sensitive to numerous different global and local stakeholders.

From the economic point of view shipbuilding industry is a long cycle business, as it is apparent from the fact that an interval between shipbuilding contract signing and ship's delivery is within one and a half and two years, depending on the ship type and state of the shipyard's production technology development. Once built, ships usually remain in service for 25 to 30 years, and consequently existing merchant ship fleet modernization rate is relatively low. Hence, economic and technological trends in shipbuilding industry develop over decades rather than years, (Stopford, 2003).

Current global shipbuilding industry and offshore plant is faced with global economic crisis and its consequences starting from the $2^{\text {nd }}$ half of the 2008 when new orders switched back in a relatively short period to the 2002 level of about $20000 \mathrm{kCGT}$, (Global Insight, 2009; SEA Europe, 2013). Since economic crisis came in the context of massive production capacities of the Far East shipyards, most of the world shipyards had to 
reduce their expenses and/or delivery periods in order to attract the potential investments, while keeping the raw material prices at the pre-crisis level, (ISSC, 2012). This particularly affected smaller shipbuilding industries such as Croatian. In addition to that, July $1^{\text {st }} 2013$ Croatia joined the European Union (EU). During the ascending process the Croatian government strongly committed to apply the EU's requirements regarding unprofitable shipyards stating that by the end of the ascending process they have to be transferred to the private sector, while governmental supports of about 90 million $\$$ at annual level can be assigned to the shipbuilding industry in the following 5 year period in order to avert possible business and social instabilities and to become viable without state support. The additional obligations that apply to Croatian shipyards include sustainable business activities as well as limitation of the production capacities leading inevitably to slipway number reduction. The only admissible governmental supports during the future shipyards' business activities can be related to the restructuring.

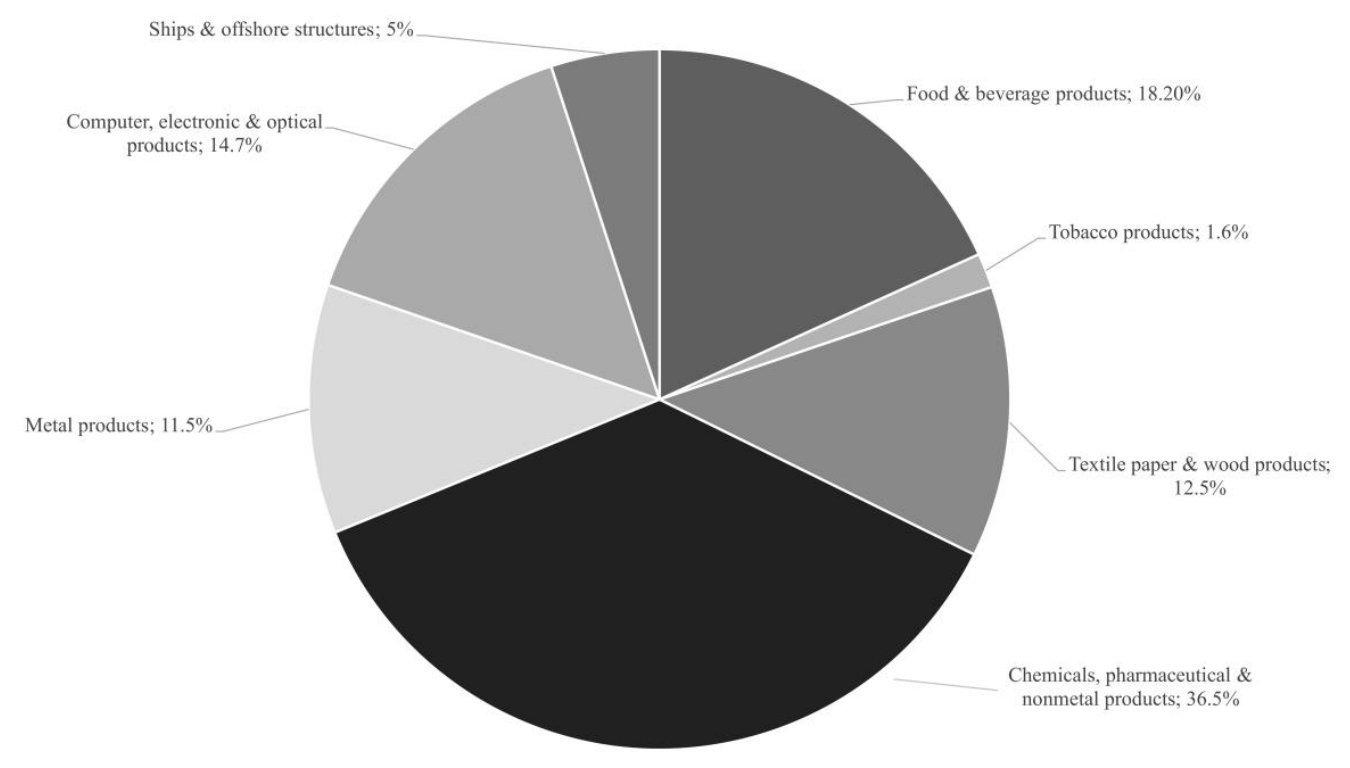

Fig. 1: Manufacturing enterprises - major income contributors, (Croatian Bureau of Statistics, 2010)

According to the register of business entities in 2008, (Croatian Bureau of Statistics, 2010), Croatian industrial enterprises engaged in industrial production include (a) mining and quarrying, (b) manufacturing, (c) electricity, gas, steam and air conditioning supply as well as (d) water supply, waste management and remediation activities. They involve 3456 enterprises with annual average of 282988 employed persons that produce total intermediate consumption of about 13 billion $\$$ and total income of products sold of about 25.5 billion $\$$. Approximately $1 / 3$ of the total income, i.e. 8.3 billion $\$$ are gained through exported products. Croatian shipbuilding industry is one of the major contributors within manufacturing enterprises that involves 371 small, medium and large companies employing approximately 20000 persons and creating total income of about 1.3 billion $\$$. Therefore, 5\% of the total Croatian industry income is generated by shipyards' production, maintenance, repairing and installation activities. It is important to point out that almost $2 / 3$ of the Croatian shipbuilding industry income are gained through export activities, indicating strong influence of the international ships and shipping market on its present status and future perspectives. Except that, there is a number of business activities within other manufacturing entities, in particular metal and nonmetal as well as computer and electronics products enterprises which are generated through existence of shipbuilding industry, making its impact on the general industry much more significant. Major industrial income contributors' share is presented in Fig. 1 including (a) food and beverage, (b) tobacco, (c) textile, paper and wood, (d) chemicals, pharmaceutical and nonmetal, (e) metal, (f) computer, electronics and optical products and (g) ships and offshore structures including main engine and equipment manufacturing and installation.

From the Croatian annual gross domestic product (GDP) point of view, manufacturing industry is the leading contributor with $14.3 \%$ of the GDP structure, i.e. almost 7.7 billion \$, (Croatian Bureau of Statistics, 2014). In 
the last decade, shipbuilding industry GDP contribution was between $0.8 \%$ and $1.8 \%$, i.e. about 0.8 billion $\$$. Also, it is important to emphasize that almost $15 \%$ share of the total Croatian export activities is accomplished by domestic shipyards, (www.hb.hr).

An importance and complexity of the shipbuilding industry is also recognized and pointed out within Croatian 2020 industrial strategy, (Republic of Croatia, 2014), including general guidelines for its future development within manufacturing industry. Croatian government is strongly committed to enhance the industrial development in order to deploy the added value manufacturing activities by stimulating the (a) industrial production growth at yearly rate of $2.8 \%$, (b) employment of additional 85000 persons, including $30 \%$ of high tech jobs, (c) the productivity increase at yearly rate of $10 \%$ as well as (d) the increase of export oriented production including at least $30 \%$ of added value products, (Republic of Croatia, 2014). A summary of activities related to industrial development is given in Fig. 2. Such a demanding task can only be accomplished by persistent investments into research and development in order to stimulate innovativeness and by implementation of new and sophisticated production technologies capable of dealing with current and globally most attractive products.

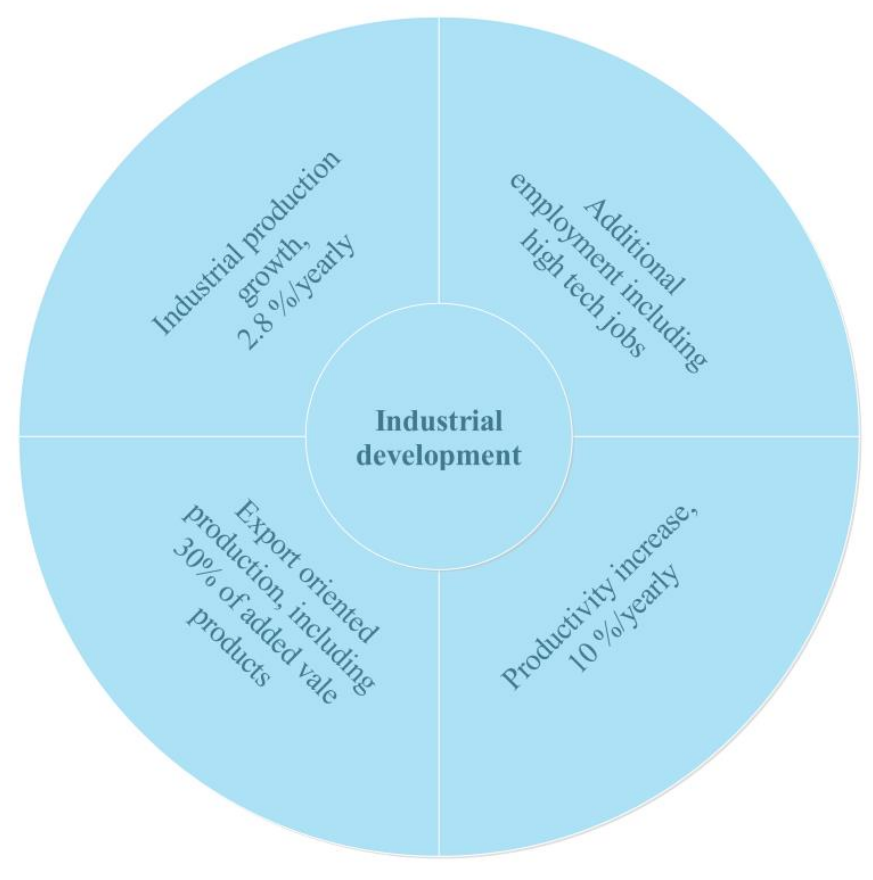

Fig. 2: Summary of activities related to industrial development

Based on the above facts, as well as on the current state of the world merchant fleet and global shipbuilding industry, future development perspectives of the Croatian shipbuilding industry are considered in this paper. Special attention is paid to the implementation of high tech and added value products that are considered to be the most interesting for the future and competitive global shipbuilding market.

\section{Croatian Shipbuilding Industry}

Croatia is a maritime country sited at the eastern part of the Adriatic Sea with more than $31000 \mathrm{~km}^{2}$ of the territorial waters and $5835 \mathrm{~km}$ of the coastline including more than 1200 inhabited islands. Traditional shipbuilding has a long history in Croatia, mainly due to small and usually family crafts. However, modern shipbuilding industry comprises 5 large, 14 medium and 352 small shipyards producing, maintaining or repairing ships and offshore structures along with scientific and professional support provided by three universities, hydrodynamic institute and classification society. Fig. 3 represents the geographical locations of 
the largest shipyards that are located in the biggest coastal cities, like the cities off Pula (Uljanik), Rijeka (3. Maj and Viktor Lenac), Split (Brodosplit) and Trogir (Brodotrogir). Usual production program consists of mostly custom made oil/product tankers, chemical tankers and bulk carriers with exception of two shipyards with much broader production capabilities, namely the Uljanik shipyard (car carriers, wagon carriers and recently dredgers) and the Brodosplit shipyard (car passenger ferries, submarines and recently heavy lift vessels). Current Croatian shipyards' state in new orders, order book and deliveries with respect to the European and global levels is presented in Tables $1-3$, respectively. It can be seen that Croatian shipbuilding industry share at appropriate level in European context (27\% in new orders, $14 \%$ in orderbook and $12 \%$ in deliveries), while it is almost negligible at the global level. However, in case of Croatia, a ratio CGT/GT takes almost a unit value that signifies a relative complexity of both ordered and delivered ships with considerable capability of its increase, i.e. enhancement of the product value and complexity.

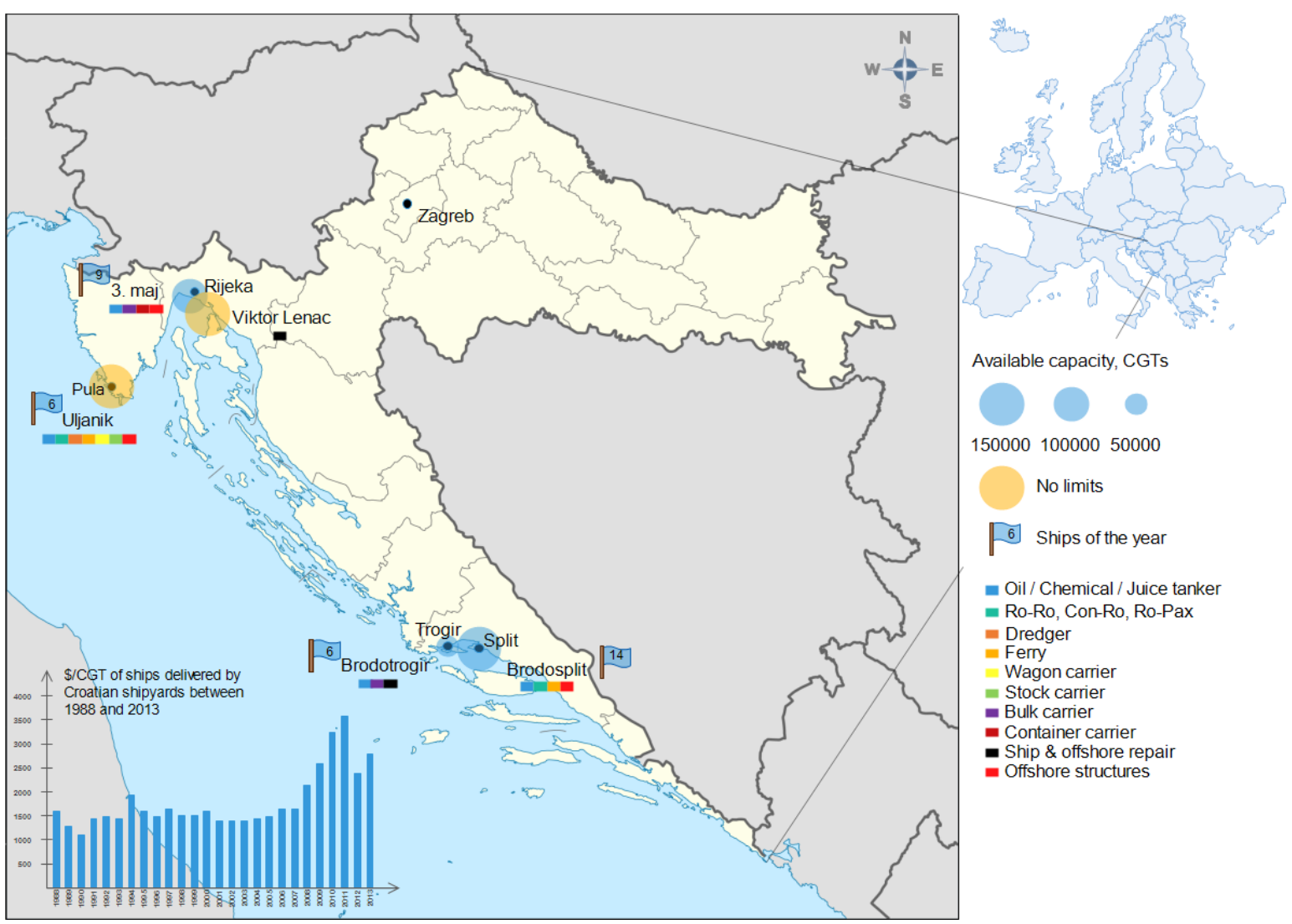

Fig. 3: Geographical position, production capacities and properties of large Croatian shipyards

Table 1: New orders of Croatian shipyards in 2013 compared to Europe and world, (SEA Europe, 2013)

\begin{tabular}{llll}
\hline & Number & 1000 GT & 1000 CGT \\
\hline Croatia & 10 & 99 & 96 \\
Europe & 79 & 187 & 356 \\
World & 2155 & 64424 & 34384 \\
\hline
\end{tabular}

Table 2: Order book of Croatian shipyards in 2013 compared to Europe and world, (SEA Europe, 2013)

\begin{tabular}{llll}
\hline & Number & 1000 GT & 1000 CGT \\
\hline Croatia & 21 & 222 & 212 \\
Europe & 281 & 1051 & 1533 \\
World & 5754 & 167659 & 93650 \\
\hline
\end{tabular}


Table 3: Deliveries of Croatian shipyards in 2013 compared to Europe and world, (SEA Europe, 2013)

\begin{tabular}{llll}
\hline & Number & 1000 GT & 1000 CGT \\
\hline Croatia & 5 & 56 & 58 \\
Europe & 102 & 319 & 498 \\
World & 2366 & 57334 & 30448 \\
\hline
\end{tabular}

According to the agreement between Croatian government and EU achieved during the ascending process, current production capacities of the Croatian large shipyards (except Uljanik and Viktor Lenac shipyards) are limited to 292358 CGTs, (Senjanović and Hadžić, 2014). Production capacities limitations for particular shipyards are summarized in Table 4 and Fig. 3. Along with that, in order to prevent possible unfair trading practices, EU suppressed any kind of governmental supports for European shipyards (except supports related to new and innovative technology). However, non-EU and primarily Far East competitors strongly rely on state supporting finance instruments and consequently commercial banks and insurance companies are focusing their business activities out of the EU portfolio, (Veža, 2008).

Table 4: Production capacities limitations, (Senjanović and Hadžić, 2014)

\begin{tabular}{ll}
\hline Shipyard & Available capacity, CGTs \\
\hline Uljanik & No limits \\
3. maj & 109570 \\
Brodosplit & 122833 \\
Brodotrogir & 59955 \\
Viktor Lenac & Only repair activities \\
\hline
\end{tabular}

Therefore, a sustainable business agenda for Croatian shipbuilding industry has to be developed in order to access the available capacities in a proper way as well as to ensure their future sustainable development. Two possible extremes can be identified, i.e. moving to market of relatively simple and low added value product with relatively low CGT, or involving in market of high tech and added value products with significant CGT value. In the former case, available production capacities can be used to manufacture a large number of products, while in the latter case a small number of products would fill them out. Current unit value trend of ships delivered by Croatian shipyards in terms of \$/CGT, Fig. 3, suggests that shipbuilding industry in Croatia moves slowly towards production of sophisticated ships and offshore structures that on one side rely on specialized research and development and on the other on strong support of the surrounding industry as well as on financial background influenced by commercial banks. Therefore, in order to enhance further development of sophisticated products in Croatian shipbuilding industry, Croatian government should immediately create and support favorable industrial, educational and scientific surroundings following the European Leader SHIP 2015 recommendations, (Veža, 2008), compliant to those available in Croatian 2020 industrial strategy, (Republic of Croatia, 2014), in particular those related to (a) increase of research and development investments, (b) improvement of financial climate, (c) innovation and prototype development and (d) interoperability and cooperations between EU and domestic shipyards.

Along with governmental activities, Croatian shipbuilding competitiveness and capability to act as global stakeholder strongly depends on shipyards' business strategy and structure, existing production capacities, personnel potentials, available investments, supplier chains, local competition, domestic and foreign shipbuilding market, etc. According to Porter, (Porter, 1980), those factors directly influence shipyard's attractiveness through five competitive forces, i.e. the entry of new competitors, the threat of substitutes, the negotiation potential of buyers and suppliers as well as rivalry among competitors, Fig. 4. The strength of each competitive force depends on industry structure and its technical characteristics and can therefore be influenced through development strategies in order to shift industry attractiveness for better or worse, (Porter, 1980). 


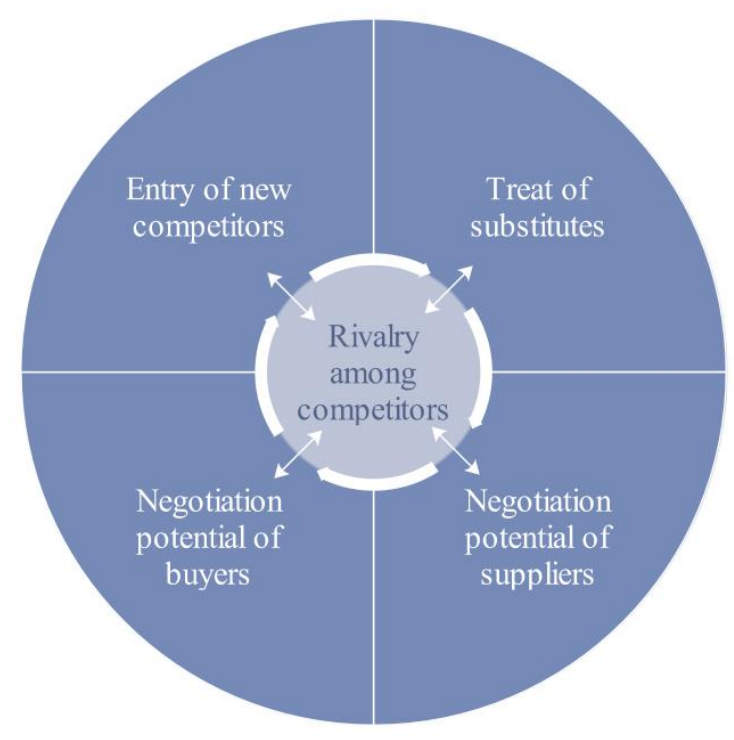

Fig. 4: Factors influencing shipbuilding competitiveness and attractiveness, (Porter, 1980)

In the context of current Croatian shipbuilding industry, the rivalry among competitors is at high level mainly due to usual production program that is similar to that of the Far East shipyards. Except that, a differentiation of products at regional level is low, as Croatian shipyards, with an exception of Uljanik shipyard, operate within a relatively similar range of ship types. On the other hand the entry of new competitors at global and regional level is limited due to different economic barriers related to high investment costs, physical obstacles (available shoreline areas, sea depth, access to the open sea, existing traffic and energy infrastructure, etc.) as well as governmental support and economic policies. The negotiation potential of buyers is currently at high level mainly due to economic crisis and massive production capacities of the Far East shipyards. Their influence is usually reflected through lower final product price, shortening of manufacturing period and requirements for innovative solutions enhancing operative properties. Except that, in the current Croatian manufacturing industry, the negotiation potential of suppliers is also relatively high, as the most of the raw material, equipment, design solutions and part of the working personnel for the shipbuilding purposes is usually imported or subcontracted separately for each shipyard (up to $75 \%$ of the final product value). Finally, since the marine traffic is the most cost effective long distance transport type, the threat of substitutes is relatively low.

In order to provide an economically sounded future perspective and guidelines for research and development it is inevitable to take all of the factors influencing shipbuilding industry competitiveness, especially those related to rivalry between competitors and negotiation potentials of investors and suppliers. Therefore, current state of the world merchant ship fleet and world shipbuilding industry is analyzed in the following sections.

\section{Current State of the World Merchant Ship Fleet}

Current state of the world merchant and special ship fleet, i.e. the negotiation potential of buyers, can be analyzed with respect to ship type, gross tonnage (GT) and years spent in service, as presented in Tables 5 and 6. The largest share in total number of ships have general cargo (20.2\%) and tug ships (18.8\%) mostly of small or medium scale, i.e. between 100 and 24999 GT, (European Maritime Safety Agency, 2013), while almost 1/4 of the world fleet share take bulk and oil/chemical carriers mainly due to very large ships, i.e. above 60000 GT, Table 5. On the other side, bulk carriers, oil/chemical tankers and container ships have the largest share in world fleet with respect to the gross tonnage, mostly due to presence of large and very large ships (above 25000 GT), Table 6. 
Table 5: World merchant and special ships with respect to their number and years in service, (European Maritime Safety Agency, 2013)

\begin{tabular}{l|lllll}
\hline \multirow{2}{*}{ Ship type } & No. & \multicolumn{4}{|c}{ No. with respect to years of service } \\
& & $0-4$ & $5-14$ & $15-25$ & +25 \\
\hline General cargo & 16061 & 2202 & 2896 & 3886 & 7077 \\
Specialized cargo & 259 & 57 & 24 & 36 & 142 \\
Container ship & 4858 & 1384 & 2290 & 999 & 158 \\
Ro-Ro ship & 1470 & 377 & 469 & 247 & 377 \\
Bulk carrier & 9892 & 4333 & 2511 & 1785 & 1263 \\
Oil and chemical carrier & 11730 & 3223 & 3716 & 2280 & 2466 \\
Gas carrier & 1578 & 441 & 471 & 375 & 291 \\
Other liquid cargo & 726 & 133 & 74 & 142 & 377 \\
Passenger ship & 6423 & 558 & 1365 & 1718 & 2782 \\
Offshore ship & 7002 & 2220 & 1735 & 459 & 2588 \\
Special ship & 4492 & 573 & 762 & 823 & 2336 \\
Tug & 14978 & 3262 & 3557 & 2253 & 5906 \\
\hline
\end{tabular}

Table 6: World merchant and special ships with respect to GT and years in service, (European Maritime Safety Agency, 2013)

\begin{tabular}{l|lllll}
\hline \multirow{2}{*}{ Ship type } & \multirow{5}{|c}{ GT with respect to years of service } \\
& GT & $0-4$ & $5-14$ & $15-25$ & +25 \\
\hline General cargo & 57025 & 14558 & 14427 & 12575 & 15466 \\
Specialized cargo & 3386 & 833 & 332 & 726 & 1495 \\
Container ship & 175627 & 69575 & 80598 & 22578 & 2875 \\
Ro-Ro ship & 44756 & 17077 & 17297 & 4932 & 5450 \\
Bulk carrier & 359521 & 185860 & 93894 & 58811 & 20956 \\
Oil and chemical carrier & 281072 & 112692 & 132496 & 29613 & 6271 \\
Gas carrier & 49826 & 19717 & 19005 & 6871 & 4233 \\
Other liquid cargo & 1233 & 440 & 261 & 216 & 316 \\
Passenger ship & 34892 & 7006 & 13799 & 7969 & 6118 \\
Offshore ship & 27968 & 8776 & 5947 & 4426 & 8819 \\
Special ship & 8806 & 1868 & 1794 & 1696 & 3449 \\
Tug & 4225 & 1027 & 1037 & 552 & 1609 \\
\hline
\end{tabular}

Except number of operating ships and their gross tonnage, an important decision making parameter is the age of world fleet in terms of certain ship type. From Tables 5 and 6 it can easily be noticed that currently the eldest fleets are those of general cargo ships as well as offshore and special ships. In particular, more than $35 \%$ of the operating offshore ships and approximately 50\% of existing special ships including 8819 GT and 3449 GT, respectively, are currently older than 25 years. Therefore, in the near future an inevitable need for renewing of the current world fleet of those ship types will occur including expansion of the world fleet with some of the new special and offshore ship types like wind turbine installation units, dredgers, drill ships, cable layers, etc. (Senjanović and Hadžić, 2014; Liščić et al., 2014; Croatian Academy of Sciences and Arts, 2014; Hadžić et al., 2014).

\section{Current State of the World Shipbuilding Industry}

The rivalry among competitors is strongly affected by the current state of the world shipbuilding industry, i.e. by geographical diversification of products, available production capacities, state of world new orders and order book market shares as well as local governmental policies and supports, as indicated in the Introduction. Current state of the world shipbuilding industry in 2013 with respect to new orders, order book and deliveries is summarized in Table 7 in terms of GT and CGT in case of China, South Korea, Japan, EU, Croatia and rest of the world (RoW). 
Table 7: Summary of the world shipbuilding industry new orders, orderbook and deliveries until 3Q 2013, (SEA Europe, 2013)

\begin{tabular}{l|lllllll}
\hline & New orders & \multicolumn{5}{c}{ Orderbook } & Deliveries \\
& $1000 \mathrm{GT}$ & $1000 \mathrm{CGT}$ & $1000 \mathrm{GT}$ & $1000 \mathrm{CGT}$ & $1000 \mathrm{GT}$ & $1000 \mathrm{CGT}$ & CGT/GT \\
\hline China & 25006 & 12640 & 63766 & 32616 & 20436 & 10479 & 0.512 \\
S. Korea & 23892 & 11795 & 56069 & 29553 & 20778 & 9864 & 0.474 \\
Japan & 8995 & 4909 & 26126 & 13138 & 11666 & 5703 & 0.488 \\
EU* & 1450 & 1434 & 4609 & 4921 & 1343 & 1492 & 1.111 \\
Croatia & 99 & 96 & 222 & 212 & 56 & 58 & 1.035 \\
RoW & 4982 & 3510 & 16867 & 13230 & 3055 & 2852 & 0.933 \\
Total & 64424 & 34384 & 167659 & 93650 & 57334 & 30448 & 0.531 \\
\hline
\end{tabular}

*Excluding Croatia

Current leading shipbuilding nation, with respect to total GT and CGT of new orders and order book, is China with $36.8 \%$ share of the total world new orders, (SEA Europe, 2013). It is followed by South Korea and Japan, while EU is at the $4^{\text {th }}$ position with almost $3 \%$ share of the world orderbook. However, in case of product complexity measured by CGT/GT, EU still has the leading role in the world, in particular some of EU members such as Italy and Netherlands, (SEA Europe, 2013), mainly due to production of complex ships like cruise and/or offshore ships. In case of Croatian shipbuilding industry product complexity takes almost a unit value due to custom made ships as well as research and development activities of the leading Croatian shipyard Uljanik. On the other side, the standard ship types mostly produced in Croatia are similar to those of the Far East shipyards. Consequently, an intensive rivalry is induced that shifts industry attractiveness by means of existing economic and political mechanisms, especially EU's regulations related to prevention of unfair trading practices, in favor of the Far East shipbuilding industry.

\section{Future Perspectives}

In the context of Croatian EU membership, future perspectives of the Croatian shipbuilding industry within global, competitive and harsh market depend mostly on the new private owners' abilities that have to be demonstrated during the incoming restructuring period. However, significant contribution to the future Croatian shipbuilding development and its impact on Croatian economy through multiplicative factor can be achieved by governmental strategies aiming to generation of favorable business and industrial surroundings. Such attempt is present within Croatian 2020 industrial strategy, particularly within general manufacturing industry development guidelines as well as within definition of development support to activities such as (a) fabrication of metal products, (b) computer and electronics manufacturing, (c) electrical equipment manufacturing and (d) machinery and equipment manufacturing, (Republic of Croatia, 2014). Along with that, favorable financial background has to be addressed as soon as possible in a thorough manner, since Croatian shipyards meet serious difficulties when trying to assure stable production financing. Therefore, crucial factors that ensure the very existence of the Croatian shipbuilding industry are stable financial background and development of domestic industrial surroundings (steel manufacturing, equipment production) that will enhance the domestic share within final product value, employment of additional persons and induce export oriented production. In such a way, the negotiation potential of suppliers would be shifted in favor of the Croatian shipyards for most of the equipment that is installed into ship as final product.

Current negotiation potential of buyers and rivalry among competitors can be successfully addressed through sustainable production agenda including sophisticated products that are different from the conventional Far East shipyards' production program and in accordance with the future development of human needs and habits. Therefore, production program should focus on three perspective market sectors, i.e. (a) energy including offshore technology objects (oil and gas platforms, offshore renewable energy sources, subsea mining systems, subsea piping) and supporting offshore and special ship fleets, (b) food including offshore mariculture objects and supporting ships and (c) entertainment including cruise ships. Although these kind of market sectors are a part of a long term global sustainable development, they are significant as the most complex shipbuilding industry products that require continuous development of the production technology and inevitable investments in educational, research and development activities. On the other side, an overall impact to the national economy 
and surrounding industry is significant, especially in case when most of the equipment is produced within domestic manufacturing industry. Finally, only this kind of technology can successfully enhance the future development of Croatian economy and ensure successful fulfillment of the goals defied within Croatian 2020 industrial strategy such as production growth, export oriented production of added value products including highly educated employers. A summary of the future perspectives of Croatian shipbuilding industry and its impact on economy, society and science and technology is given in Fig. 5.

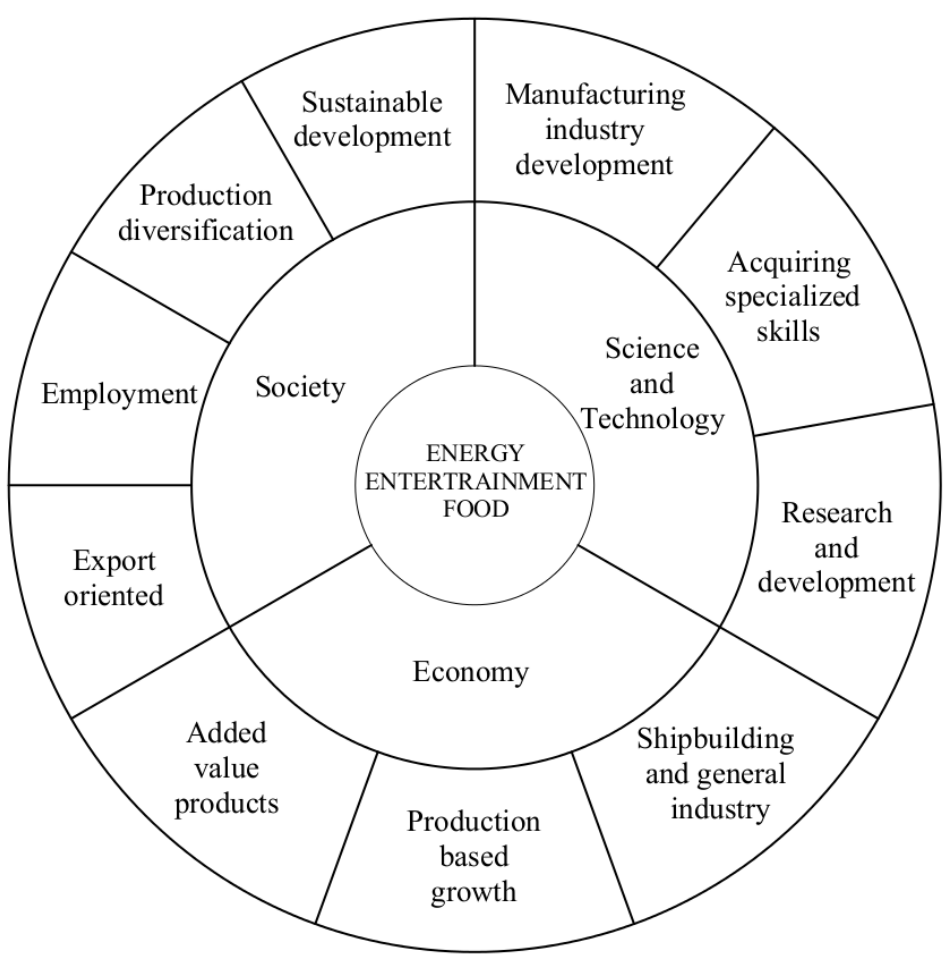

Fig. 5: Summary of the future perspectives of Croatian shipbuilding industry

\section{Conclusion}

Shipbuilding is one of the most important manufacturing industries in Croatia that contributes significant income to the Croatian economy through its production, maintenance, repairing and installation activities. Except that, it is considered as industrial prime mover creating new jobs and enhancing local and regional community development manifested through industrial surrounding multiplicative factor. Current Croatian shipbuilding industry is almost negligible in the context of global shipbuilding. However, it has a significant role within national economy and EU since it produces custom made and relatively complex products with considerable perspective of their value and complexity enhancement. Therefore, it is important to develop a sustainable business agenda for the Croatian shipbuilding industry that will incorporate EU requirements, new owners' perspectives, current state of the world shipping and shipbuilding industries, as well as need and interests of the domestic manufacturing stakeholders and personnel involved in product design, manufacturing and maintenance.

One of the most important factors influencing Croatian shipbuilding perspectives are stable financial background and development of the domestic industrial surroundings that could shift the negotiation potential of suppliers in favor of Croatian shipyards. On the other side, negotiation potential of buyers and rivalry between competitors can be addressed through production program involving products related to energy, food and entertainment market sectors. Such business agenda is in accordance with the Croatian 2020 industrial strategy and European Leader SHIP 2015 recommendations and would consequently influence different aspects of society, science and technology as well as the Croatian economy. 


\section{References}

Croatian Academy of Sciences and Arts, (2014): Morska tehnologija (Offshore Technology) - perspektivno područje za Republiku Hrvatsku, Zagreb. ISSN 1331-6818

Croatian Bureau of Statistics, (2010): Statistical reports - Main Structural-business Indicators on Industry in 2008, Zagreb.

Croatian Bureau of Statistics, (2014): Annual Gross Domestic Product for 2012, Zagreb.

European Maritime Safety Agency, (2013): Equasis, The World Merchant Fleet in 2012, Lisbon.

Global Insight, (2009): An Evaluation of Maritime Policy in Meeting the Commercial and Security Needs of the United States.

Hadžić, N, Kozmar, H, Tomić, M., (2014): Offshore Renewable Energy in the Adriatic Sea with Respect to the Croatian 2020 Energy Strategy, Renewable and Sustainable Energy Reviews, 40: $597 \quad-607$. http://dx.doi.org/10.1016/j.rser.2014.07.196

ISSC, The 18th International Ship and Offshore Structures Congress, (2012): Committee V.3 - Materials and Fabrication Technology, Rostock, Germany. ISBN 978-3-8770-131-\{5,8\}

Kersan-Škabić, I., (2009): Bodogradnja u Europskoj uniji i Hrvatskoj - Realnost i izazovi, Ekonomska misao i praksa, 2: 373-396. (In Croatian) UDK / UDC: 629.12.01(339.923:061.1/497.13)

Liščić, B., Senjanović, I., Čorić, V., Kozmar, H., Tomić, M., Hadžić, N., (2014): Offshore Wind Power Plant in the Adriatic Sea: An Opportunity for the Croatian Economy, Transactions on Maritime Science, 2: 103-110. http://dx.doi.org/10.7225/toms.v03.n02.001

Perić Hadžić, A., Karačić, T, (2013): Restrukturiranje hrvatske brodogradnje u kontekstu pristupanja Europskoj Uniji, Pomorski zbornik 47-48: 121-132. (In Croatian) UDK: 332.025.28 629.5(497.5:4-6EU)

Porter, M.E., (1980): Competitive Strategy: Techniques for Analyzing Industries and Competitors, The Free Press, New York. ISBN 0-684-84746-0

Republic of Croatia, Ministry of Economy, (2014): Croatian 2020 Industrial Strategy, Zagreb.

SEA Europe, (2013): Shipbuilding Market Monitoring, 1 - 3Q 2013, Brussel.

Senjanović, I., Hadžić, N., (2014): Potencijali Hrvatske brodogradnje. In: G. Družić, I. Družić (Eds.) Razvojni potencijali hrvatskog gospodarstva, Croatian Academy of Sciences and Arts, Zagreb. (In Croatian) ISBN 978953-154-279-1

Stopford, M., (2003): Maritime Economics, 2nd edition, Taylor \& Francis, New York. ISBN 978-0-415-153102

Veža, I., (2008): Restructuring of the Croatian Shipbuilding Industry, Economic Research Center, Nagoya University.

www.hb.hr (accessed on September 29, 2014) 